Article

\title{
Where Symbolism Prospers: An Analysis of the Impact on Enabling Rights of Labour Standards Provisions in Trade Agreements with South Korea
}

\author{
Gerda Van Roozendaal \\ Department of International Relations and International Organization, Faculty of Arts, University of Groningen, 9700 AS \\ Groningen, The Netherlands; E-Mail: g.c.van.roozendaal@rug.nl
}

Submitted: 30 June 2017 | Accepted: 22 September 2017 | Published: 14 December 2017

\begin{abstract}
Can trade agreements be used as a tool for improving the conditions under which people work? The evidence from this study suggests this is not the case, even if the country in question-in this instance South Korea-is a well-developed and democratic country. While over the past six years South Korea has taken part in a number of Free Trade Agreements containing labour provisions, the impact of these on enabling rights has been rather low. This would suggest that without the willingness to enforce these parts of the agreements, or without the willingness to implement them on the Korean side, the inclusion of such provisions remains a fairly symbolic undertaking.
\end{abstract}

\section{Keywords}

Free Trade Agreements; labour; labour standards; South Korea; trade

\section{Issue}

This article is part of the issue "Labour Standards in a Global Environment", edited by Gerda Van Roozendaal (University of Groningen, The Netherlands) and Jan Orbie (Ghent University, Belgium).

(C) 2017 by the author; licensee Cogitatio (Lisbon, Portugal). This article is licensed under a Creative Commons Attribution 4.0 International License (CC BY).

\section{Introduction}

The large amount of Free Trade Agreements (FTAs) that have been negotiated over the past 25 years-by now involving all World Trade Organization (WTO) members (WTO, 2017a)-demonstrates the importance that States attach to increasing trade as an engine for economic growth. However, FTAs might also lead to a situation in which countries try to increase their competitiveness by continuously keeping their labour standards lower than other countries, or even lowering them. This concern is illustrated by a recent statement of international trade unions: "International trade and investment agreements have contributed to growing imbalances between and within countries. Opaque negotiation processes resulted in one-sided protection of investors' rights, while labour and social rights...came under attack" (Labour 20 [L20], 2017).
While research on the relationship between FTAs and labour protection has resulted in mixed outcomes, ${ }^{1}$ FTAs are increasingly seen as providing an opportunity to set minimum standards for the signatory countries. This is illustrated by the fact that in 2013 , almost $25 \%$ of the trade agreements registered at the WTO as being concluded or notified included labour standards provisions (International Labour Organization [ILO], 2015, p. 19). Although such inclusion could be perceived as a demonstration of a protectionist interest, it can also be viewed as an illustration of a concern for other matters related to trade than purely economic ones. Whichever argument prevails, labour standards provisions make trade agreements easier to accept for those critical of the social effects of globalisation in general and trade agreements in particular. As such, the provisions increase support for trade agreements in more developed countries. $^{2}$

\footnotetext{
${ }^{1}$ For example, research by Davies and Vadlamannati (2013) and Olney (2013) found that countries compete in the area of labour standards to attract foreign direct investment, while Potrafke (2013) argues that globalization does not lead to a deregulation of the labour market.

${ }^{2}$ See Van Roozendaal (2015).
} 
But are these provisions just paying lip service to labour standards' improvements? This article uses the case of South Korea to show how its many FTAs formulate different labour standards provisions, and analyses the effects of this comprehensive body of commitments and accompanying instruments. It concludes that the effects are largely symbolic.

\section{The Korean Case}

Until now research has shown that labour provisions in trade agreements have had a limited influence on actual labour standards. It has been suggested that more in-depth case studies are required to identify possible effects (Giumelli \& Van Roozendaal, 2016). This article, presenting an in-depth study of Korea, ${ }^{3}$ analyses the effects of a set of provisions in the agreements related to the fundamental enabling conventions in the field of freedom of association and the right to organise. ${ }^{4}$ Korea is interesting because it is a democratic and developed country (Freedom House, 2017; World Bank, 2017), which suggests it potentially has the political will and means to maintain a high level of labour standards. The importance of democracy for enabling labour rights was pointed out by, amongst others, Greenhill, Mosley and Prakash (2009, p. 678), ${ }^{5}$ and the importance of economic development by Giumelli and Van Roozendaal (2016, pp. 56-57). In addition, the potential influence of dependence on FTA partner countries as export destinations was shown by Frankowski (2015, pp. 11-12), Greenhill et al. (2009) and Meunier and Nicolaïdis (2006). The US and the EU, two of its FTA partners, were in 2014 the second and third export destination (almost $20 \%$ of its exports). While this is by no means "dependency", it could make a difference.

The study takes a different approach than most of the other research on labour provisions in trade agreements; instead of focussing on one FTA, it takes a countryKorea-as a point of departure and looks at the impact of all FTAs incorporating labour standards. It demonstrates that even though these agreements together include a broad range of provisions, there are no effects on enabling rights. This is interesting, not only due to the potential for change on the receiving end as was just pointed out, but also due to the fact that the trade agreements facilitate different kinds of institutional arrangements which enable implementation, and involve a wide variety of trading partners, including major ones who should be able to exert pressure.

In order to assess the effectiveness of the FTAs' labour provisions on the ratification of the enabling fundamental Conventions and the related laws and prac- tices, this article uses a simple definition of effectiveness of the Korean FTAs, making a difference between output and impact, the former referring to "the norms, principles and rules constituting the regime itself" and the latter to "the set of consequences flowing from the implementation of and adjustment to that regime" (Underdal, 1992, p. 230). Referring to van den Putte (2016), Orbie and Van Roozendaal point out in the editorial of this special issue that impact refers to intermediate impact (development, empowerment, institution building and legal improvement) and ultimate impact (labour practices). Whether such impact is positive can be measured against the "relative improvement standard". This standard is met when the inclusion of a provision leads to an improvement in the situation relative to that which existed before (Underdal, 1992, p. 231).

This article analyses the different Korean FTAs that include labour standards to understand what kind of conditions and incentives they contain (the output). This is followed by an analysis of the effects and an explanation of the lack of effect (the impact). The output will be assessed on the basis of the original texts of the agreements, while the impact will be assessed through a systematic analysis of reports of the US Department of State (US DOS), the US Department of Labor (US DOL), UN reports (Special Rapporteur on the rights to freedom of peaceful assembly and of association; ILO Committee on the Application of Standards; ILO Committee on the Freedom of Association [CFA]) and the International Trade Union Confederation (ITUC).

\section{The Output: Labour Provisions in Korean FTAs}

At the beginning of 2017, Korea had signed 16 FTAs (Asia Regional Integration Center [ARIC], n.d.), eight of which include substantial and distinctive references to labour standards. The eight with substantial references can be distinguished along the lines of: (1) the content, i.e. the kind of labour standards they refer to and the strength of the wording, and (2) the procedures (or implementation mechanisms) in place to ensure or stimulate compliance (see part 4).

\subsection{EU-Korea FTA as an Example}

With respect to the content, one can usually make a difference between references to the principles or rights enshrined in the core labour standards $(C L S)^{6}$ of the ILO as a baseline (ILO, 2012, pp. 1-2), or to references to an alternative package.

The FTA of Korea with the EU, ${ }^{7}$ effectuated in July

\footnotetext{
${ }^{3}$ In this article, South Korea will be referred to as Korea.

4 "enabling rights make it possible to promote and realize decent conditions at work" (ILO, 2017a).

${ }^{5}$ However, the study of Giumelli and Van Roozendaal (2016, p. 19), which equated political will with democracy, did not see an effect of being a democratic country on the level of respect for labour rights. Given the fact that others found other results, this variable should not be ruled out.

${ }^{6} \mathrm{CLS}$ refer to the rights and principles being part of Conventions 29 and 105 (on forced labour), 87 and 98 (on freedom of association and right to organise), 100 and 111 (non-discrimination) and child labour (138 and 182) (ILO, 2012, p. 1).

${ }^{7}$ The full text of the FTAs referred to in this article can be found on the website of the Korean Ministry of Trade, Industry and Energy: http://english. motie.go.kr/en/if/ftanetwork/ftanetwork.jsp
} 
2011, is in terms of content the most comprehensive one and will, therefore, be used as an example. It specifically refers to Article 13.4.3 to CLS. Its international commitments includes "respecting, promoting and realising, in their laws and practices, the principles concerning the fundamental rights" and reaffirms "the commitment to effectively implementing the ILO Conventions that Korea and the Member States of the EU have ratified respectively" (Article 13.4.3), and to "make continued and sustained efforts towards ratifying the fundamental ILO Conventions as well as the other Conventions that are classified as 'up-to-date' by the ILO" (Article 13.4.3).

With a national focus, the FTA specifies that "(a) Party shall not fail to effectively enforce its...labour laws, through a sustained or recurring course of action or inaction, in a manner affecting trade or investment between the Parties" (Article 13.7.1). At the same time, the FTA instructs that "the Parties shall not weaken or reduce the...labour protections afforded in its laws to encourage trade or investment, by waiving or otherwise derogate from...its laws, regulations or standards, in a manner affecting trade or investment between the Parties" (Article 13.7.2).

\subsection{Other FTAs}

With respect to international efforts on the content, the FTAs with the US, Canada and Turkey all commit to CLS in a similar fashion as the EU-Korea FTA does, while others make use of a weaker formulation such as "shall endeavour to adopt and maintain" (FTA with Peru and Australia) or "shall strive to adopt and maintain" (FTAs with Colombia and New Zealand).

With the exception of the FTA with the EU, none of the FTAs oblige the parties to ratify the ILO Conventions related to CLS, nor do they discuss the up-to-date Conventions. However, the Canada-Korea agreement has a longer list of internationally recognised labour rights, extending it to employment standards in terms of wages, occupation injuries and payments, and nondiscrimination of migrant workers (Article 8.2).

Just like the EU FTA, the FTA with Turkey also specifically urges the Parties to effectively implement the ratified ILO Conventions. However, without an appeal to also ratify these ILO Conventions, this FTA should be considered weaker than the EU-Korea FTA.

With respect to the references to domestic laws, all FTAs include: (1) a commitment to enforce domestic labour laws that have an effect on trade and investment, and (2) a commitment not to weaken domestic labour laws that have an effect on trade and investment.

Of the two, the first is formulated in the US-Korea FTA as "neither Party shall fail to effectively enforce its labor laws, including those it adopts or maintains in accordance with Article 19.2.1, through a sustained or recurring course of action or inaction, in a manner affecting trade or investment between the parties" (Article 19.3.1[a] of the US-Korea FTA). ${ }^{8}$ However, in the case of this FTA, Article 19.8 explicitly limits the phrase "labour laws" to those laws covering CLS plus acceptable conditions of work.

A phrase on not to weaken labour law in so far it affects trade or investment is included in all FTAs. However, here one can also find different formulations. Again, in the Korean FTAs with Canada, the US, Australia, New Zealand and Peru references are made to those laws in the area of the CLS. Canada refers to the extended list here. To illustrate, in Article 18.2.2 of the Peru-Korea maintains that "the Parties shall not waive or otherwise derogate from...their laws or regulations implementing Article 18.1, in a manner substantially affecting trade or investment between the Parties, where the waiver or derogation would be inconsistent with the principles as stated in the ILO Declaration". This suggests that the laws already in place but not related to the CLS could indeed be weakened. However, the FTA with Turkey includes a more comprehensive formulation, i.e. "each Party shall not weaken or reduce the...labour protections afforded in its laws to encourage trade and investment, by waiving or otherwise derogating from...regulations or standards, in a manner affecting trade or investment between the Parties" (Article 5.7.2). Here, the point of reference concerns the domestic legislation and not only CLS-related principles and therefore offers more potential than the Peru-Korea FTA, but is still potentially weaker than the EU-Korea FTA, as there is nothing in the Turkey-Korea agreement on ratifying the Conventions related to CLS. A ratified Convention entails stronger commitments than a CLS, which makes the EU-Korea FTA with its incentive to ratify stronger than the Turkey-Korean one. A similar observation regarding the Turkey-Korea FTA can be made concerning the Colombia-Korea FTA.

In sum, the references on enforcement and derogation can be broad and restricted at the same time. Broad because in some cases domestic labour law is included, and not only the laws connected to CLS. This avoids the limitation of some of the FTAs in their reference on "waive and derogate" that all other-non-CLS related domestic law affecting trade-can be weakened. ${ }^{9}$ Another limitation is the connection made to trade in both references. In addition, with respect to CLS, the references can be limited in another way. In cases where CLS are not part of domestic law, both references only have meaning for CLS if the FTAs also contain a strong commitment to include CLS in domestic law.

\subsection{Additional References on Protectionism}

Additional references in the FTAs are at times made to not using labour standards for protectionist purposes, such as is done in the FTAs with the EU, New Zealand, Australia and Turkey. For example, the Australia-Korea agreement specifies that "each Party recognises that it

\footnotetext{
${ }^{8}$ Article 19.2.1 refers to CLS.

${ }^{9}$ A similar observation can be made with respect to the enforcement reference in the US-Korea FTA.
} 
is inappropriate to use its labour laws, regulations, practices and policies for trade protectionist purposes" (Article 17.1.5). Article 13.2.2. of the EU-Korea FTA and article 5.2.1 of the Turkey-Korea FTA are even stronger with respect to this commitment; "The Parties stress that...labour standards should not be used for protectionist trade purposes". Article 15.2.5 of the New ZealandKorea FTA is stronger as it specifies that "each Party shall ensure that its labour laws, regulations, policies and practices shall not be used for trade protectionist purposes". Especially in the cases of Australia and New Zealand, such references could also be viewed as a (in case of Australia-weak) substitute for restricting the "waive and derogate" formulation to CLS. However, as the New Zealand and Australia FTAs have only a weak commitment to including CLS in domestic laws, expectations are low regarding the obligations. The above is summarised in the table.

When taken together, the body of FTA commitments applying to Korea that include: (1) an appeal to Korea to ratify the ILO Conventions related to CLS, as well as the up-to-date Conventions, as well as commitments to (2) implementing ratified ILO Conventions; (3) realising additional internationally recognised labour rights; (4) not failing to enforce domestic labour laws, including those related to CLS when it is affecting trade and investment, and (5) not weakening domestic regulation (also covering $\mathrm{CLS}$ ) in order to increase competitiveness.

Table 1. The content of the FTAs with Korea.

\begin{tabular}{|c|c|c|c|c|c|c|}
\hline $\begin{array}{l}\text { Agreements in } \\
\text { order of date } \\
\text { of enforcement }\end{array}$ & $\begin{array}{l}\text { Strong } \\
\text { commitment to } \\
\text { CLS in domestic } \\
\text { laws and } \\
\text { regulations }\end{array}$ & $\begin{array}{l}\text { Ratification } \\
\text { of } \\
\text { conventions } \\
\text { promoted }\end{array}$ & $\begin{array}{l}\text { Commitment } \\
\text { to } \\
\text { implement } \\
\text { ratified } \\
\text { Conventions }\end{array}$ & $\begin{array}{l}\text { Not failing } \\
\text { to enforce } \\
\text { domestic } \\
\text { labour } \\
\text { laws* }\end{array}$ & $\begin{array}{l}\text { Not to waive } \\
\text { and derogate } \\
\text { from domestic } \\
\text { labour laws } \\
\text { (general or } \\
\text { related to } \\
\text { CLS)** }\end{array}$ & $\begin{array}{l}\text { Protectionism } \\
\text { reference }\end{array}$ \\
\hline $\begin{array}{l}\text { EU-Korea } \\
\text { (July 2011) }\end{array}$ & $\begin{array}{l}\text { Yes (and } \\
\text { up-to-date } \\
\text { Conventions) }\end{array}$ & Yes & Yes & Yes & $\begin{array}{l}\text { Domestic laws } \\
\text { and CLS } \\
\text { (through } \\
\text { ratification } \\
\text { reference) }\end{array}$ & Yes \\
\hline $\begin{array}{l}\text { Peru-Korea } \\
\text { (August 2011) }\end{array}$ & $\begin{array}{l}\text { No (weak } \\
\text { formulation) }\end{array}$ & No & No & Yes & Limited to CLS & No \\
\hline $\begin{array}{l}\text { US-Korea } \\
\text { (March 2012) }\end{array}$ & Yes & No & No & $\begin{array}{l}\text { Yes, but } \\
\text { limited to } \\
\text { CLS and } \\
\text { acceptable } \\
\text { conditions } \\
\text { of work }\end{array}$ & Limited to CLS & No \\
\hline $\begin{array}{l}\text { Turkey-Korea } \\
\text { (May 2013) }\end{array}$ & Yes & No & Yes & Yes & $\begin{array}{l}\text { Domestic } \\
\text { laws and } \\
\text { "protectionism } \\
\text { reference" }\end{array}$ & Yes \\
\hline $\begin{array}{l}\text { Australia-Korea } \\
\text { (December 2014) }\end{array}$ & $\begin{array}{l}\text { No (weak } \\
\text { formulation) }\end{array}$ & No & No & Yes & Limited to CLS & $\begin{array}{l}\text { Yes (weak } \\
\text { formulation) }\end{array}$ \\
\hline $\begin{array}{l}\text { Canada-Korea } \\
\text { (January 2015) }\end{array}$ & $\begin{array}{l}\text { Yes } \\
\text { (extended list) }\end{array}$ & No & No & $\begin{array}{l}\text { Yes, but } \\
\text { limited to } \\
\text { "mutually- } \\
\text { recognized } \\
\text { labour law" }\end{array}$ & $\begin{array}{l}\text { Limited to CLS } \\
\text { (but extended } \\
\text { list) }\end{array}$ & No \\
\hline $\begin{array}{l}\text { Colombia-Korea } \\
\text { (July 2015) }\end{array}$ & $\begin{array}{l}\text { No (weak } \\
\text { formulation) }\end{array}$ & No & No & Yes & Domestic laws & No \\
\hline $\begin{array}{l}\text { New Zealand-Korea } \\
\text { (December 2015) }\end{array}$ & $\begin{array}{l}\text { No (weak } \\
\text { formulation) }\end{array}$ & No & No & Yes & Limited to CLS & Yes \\
\hline
\end{tabular}

* Those FTAs with a strong commitment to adopting CLS in domestic legislation will also cover, implicitly, CLS.

** See previous note. 


\section{The Output: Implementation Mechanisms of the Agreements}

The agreements discussed above are to be implemented through a number of instruments, such as monitoring arrangements, and may provide for weaker or stronger dispute settlement procedures. They have established bodies concerned with the implementation of the agreement which serve as contact points for the parties and facilitate cooperation between them. However, the main differences between the FTAs are whether they allow, or even mandate, the involvement of the public, by for example accepting complaints and whether it is possible to use the agreement's dispute settlement, whether another kind of mechanism is devised, or whether disputes should be resolved through dialogue. Related to this is the question whether or not the bodies handling disputes have any sort of independence.

\subsection{Institutions and Accessibility}

In terms of the institutions and their accessibility, the US-Korea FTA combines individual communications (the option to file complaints by individuals or organizations) with the involvement of "the public" on a national and international level (van den Putte, 2015). Nationally, the US-Korea FTA specifically allows for - but does not require - the involvement of stakeholders to advise on the implementation (Article 19.5.4.). On the US side, this FTA is monitored by a national advisory committee (NAC), which advises the Department of Labor and the US Trade Representative. NAC includes representatives from the public (often experts from academia), business and labour (US DOL, 2017a). Internationally, article 19.5.1 provides for the establishment of the Labor Affairs Council (LAC), made up of representatives of the Ministries of the Parties. The LAC is concerned with discussing the implementation of the labour provisions, including discussing them with the public. In addition, under article 19.5.3 the Parties need to provide an opportunity for people to submit communications to be reviewed by the labour ministry of each country, which will decide whether it is willing to proceed with them. The FTA with Canada also allows for the submission of communications by the public to a governmental organisation (Article 18.10).

In terms of public involvement, the EU-Korea agreement has put more emphasis on collective approach than the US and Canadian agreements. This FTA requires that a Committee on Trade and Sustainable Development (consisting of government officials) be founded and requires each Party to "establish a Domestic Advisory Group(s) on sustainable development (environment and labour) with the task of advising on the implementation of this Chapter" (Article 13.12.4). Such a Group involves "independent representative organisations of civil society in a balanced representation of environment, labour and business organisations as well as other relevant stakeholders" (Article 13.12.5). It is required that the members of these groups will meet-in principleonce a year in the form of a civil society forum to discuss "encompassing sustainable development aspects of trade relations between the Parties" (Article 13.3.1). The Parties can inform the Forum on further developments concerning the implementation of the Chapter, and the opinion of the Forum can be brought to the attention of the Parties and the Domestic Advisory Groups. The New Zealand-Korea FTA allows specifically for its Labour Committee (comprising of government officials), established under the agreement, to consult with stakeholders (Article 15.4.5), but this is not a requirement. The FTAs with Colombia, Peru, Australia, and Turkey do not allow for the receipt of individual complaints; neither do they provide other opportunities for public involvement.

\subsection{Dispute Settlement}

In terms of the settlement of disputes, the US-Korea FTA is the most comprehensive. In the US-Korea FTA, disputes arising from the agreement may be settled in different ways. By means of Article 19.7, after consultations have failed, the dispute settlement chapter can be evoked. The Panel involved in this dispute settlement should be independent and can decide to evoke measures, including trade sanctions, that are similar to those used for other parts of the agreement, to enforce labour provision obligations (Grimmett, 2012). ${ }^{10}$ Under the Canada-Korea FTA a procedure is available which allows for fines in the form of an "annual monetary assessment equivalent to the degree of adverse trade effects related to the non-compliance" (Annex 18-E). It does not allow the regular FTA dispute settlement procedure to be evoked for this article. The article further mandates this fine to be used to implement "the action plan or other appropriate measures" (Canada-Korea FTA). Both FTAs stipulate that violations can only be established in so far as these violations have an effect on trade and investment.

All the other agreements have weaker provisions, excluding sanctions. The EU-Korea FTA does not allow for the general dispute settlement mechanism to be applied to the labour chapter. Instead, it has devised a specific mechanism for this purpose. The Committee on Trade and Sustainable Development (CTSD) could be involved if Parties are unable to solve an issue and request the Committee to come up with a solution. The Committee may consult the Domestic Advisory Group(s), which may also provide their opinion without being consulted. In case of there being a dispute the Parties cannot resolve themselves; they may request the involvement of a Panel of Independent Experts. The Panel's conclusions are, how-

\footnotetext{
10 However, a side letter exchange between the US and Korea shows that both Parties agree that when communications are requested on a certain topic not only should this be first handled domestically, but the matter should not be already under consideration by an international body and should not be already subject to another communication between the parties (United States Trade Representative, 2007).
} 
ever, non-binding and there is no provision for sanctions (Durán, 2013, p. 138). The FTAs with Colombia, Peru, Australia, New Zealand and Turkey have also chosen to settle disputes through dialogue. In these cases, there is no independent mechanism available, and there are no enforcement mechanisms.

In sum, when all the FTAs' commitments on implementation are taken into account, they refer to a body of commitments applying to Korea that include: (1) the undertaking of cooperation activities; ${ }^{11}$ (2) the involvement of civil society; (3) the opportunity to file complaints; (4) procedures to deal with disputes, which could involve independent experts, as well as (5) the application of sanctions. The question now is whether all these institutional arrangements have affected change in law or practice in Korea in the area of the right to organise and the right to freedom of association.

\section{The Impact of the Agreements}

The above shows that together the agreements containing labour references amount to a comprehensive body of language and implementation instruments. It will be analysed whether any of the instruments involving civil society, filing of complaints, enactment of dispute procedures, and the application of sanctions have been used. The first FTA with Korea containing labour standards, the one with the EU, came into force in mid-2011. That year will, therefore, be the starting point of the analysis.

\subsection{Impact on Ratification}

With respect to the ratification, there is no intermediate impact of the FTAs. Korea has not ratified Conventions 87 and 98 (covering the freedom of association, right to organise and the right to collective bargaining) (ILO, 2017b). In 2016 the Korean government made clear that it could not, due to "legal incompatibilities", ratify these two Conventions, nor Conventions 29 and 105 (ILO, 2017c, 3, 6, 10). ${ }^{12}$

\subsection{Other Kinds of Impact}

The assessment of the situation in Korea differs greatly. In 2011, a report of the US DOL concluded that "the ROK's labor laws and practices are largely consistent with international standards governing the internationally recognized labor rights articulated in Chapter 19 of the KORUS", to a great extent due to Korea's accession to the OECD (US DOL, 2011, p. 10). On the other hand, the ITUC (2016a) classifies Korea as a country where workers' enabling rights are not guaranteed by law. It rated the country with a five, meaning that it is amongst "the worst countries in the world to work in" (ITUC, 2016a, 2016b). As five is the second worst category, ${ }^{13}$ it is safe to assume that the FTAs which have been signed did not improve the situation.

Whatever the general observation, it is clear that there are significant problems in the areas of freedom of association and the right to collective action, as well as with regards to the right to strike. While these rights are guaranteed for most workers, there are important exceptions and omissions in the law that have not been amended following the conclusion of the FTAs, and neither have the practices been changed; for this Korea received strong criticism. ${ }^{14}$

\subsection{Specific Problems}

\subsubsection{Freedom of Association}

National laws may deny, restrict or not acknowledge the freedom of association and collective bargaining of certain categories of workers, such as defence industry workers, teachers, particular categories of public officials, undocumented workers, those that have been dismissed or self-employed workers, and as the 2016 UN's Special Rapporteur's report illustrates, these limitations have not been lifted since the FTAs came into force (Special Rapporteur on the rights to freedom of peaceful assembly and of association, 2016, pp. 12-13).

Some associations, such as of those who are selfemployed, are not acknowledged under Korean law. Some transportation and construction workers are included in this category. Any agreement such organisation makes is therefore non-binding. Unions allowing membership to people who have been dismissed face denial of registration or the de-certification of the whole union. In the case of the Korean Teachers and Education Workers Union, this means that 60,000 people cannot organise because of the membership of nine fired workers, while the 10,000 public servants who are allowed to be members of the Korean Government Employees Union (KGEU) cannot be represented as the union's constitution does not rule out the membership of dismissed workers (Special Rapporteur on the rights to freedom of peaceful assembly and of association, 2016, p. 13). Even when the KGEU amended its constitution, the Korean government denied registration of the union on grounds of "alleged lack of political neutrality" (Domestic Advisory Group-EU

\footnotetext{
11 Cooperation activities will not be discussed in this article as cooperation is not exclusively part of trade agreements but can take place through multiple forms, which makes it difficult to understand the specific effects of cooperation under FTAs.

12 Korea has also not ratified Conventions 29 and 105 (on forced labour) due to "inability" (ILO, 2017c, p. 10). The other fundamental Conventions, 138 and 182 (on child labour) and 110 and 111 (non-discrimination,) were ratified before 2004. The FTAs discussed in this article involve countries with different levels of ratification, from the EU countries, having signed Conventions 87 and 98, and the US failing to have signed both (ILO, 2017b).

13 The categories range from 1 (the best protection) to $5+$ (the worst protection). In the 5+ category are countries that do not guarantee workers' rights, as the rule of law is not respected. In category 5 countries "legislation may spell out certain rights workers have effectively no access to these rights and are therefore exposed to autocratic regimes and unfair labour practices" (ITUC, 2016b).

14 The length of the article does not allow a detailed overview of all laws and practices related to the enabling rights. Such overview is provided by the 2016 report of the UN's Special Rapporteur on the rights to freedom of peaceful assembly and of association, and the 2011 report of the US DOL.
} 
[DAG-EU], 2014). In general, teachers are granted the freedom of association, but only under certain conditions. The law permits the blocking of the teachers' union and public officials from engaging the political activities, providing a very broad interpretation of what political activities entail, which strongly limits the possibility of these groups to voice their concerns which has been heavily criticised by the ILO (Special Rapporteur on the rights to freedom of peaceful assembly and of association, 2016, p. 12; US DOL, 2011, pp. 17-19). In addition, unions of teachers and public officials have restricted rights with respect to what is collectively bargained for (US DOS, 2010, p. 19, 2017, p. 28).

Certain categories of public officials are not permitted to join a union at all. In 2010 the Korean Federation of Trade Unions (KCTU) and its affiliated Korean Professors Trade Union filed a complaint to the ILO's CFA, as this subcategory of teachers is not granted the right to organise. The CFA concluded that revision of the law was needed to amend this restriction (CFA, 2010), a revision which still has yet to be made.

In 2011, undocumented immigrants were not granted the right to join a union. ${ }^{15}$ The Migrants' Trade Union (MTU) was established in 2005 but was not recognised on grounds that there were undocumented workers among its members. It took the courts years to decide upon this case, which led the ILO's Committee on Freedom of Association to express its concerns about this and about the infringement of trade union activities of migrants in general (CFA, 2010, 2011, 2013; US DOL, 2011 , p. 14). In 2015, the Supreme Court ruled that undocumented migrants also have a right to organise (ITUC, 2015), leading to the recognition of MTU. ${ }^{16}$

\subsubsection{Right to Strike}

The right to strike is also severely limited. All public servants, defence industry workers and teachers are denied the right to strike, as well as those working in essential public services, the latter category again being very broadly defined. Many of these limitations conflict with international law (Special Rapporteur on the rights to freedom of peaceful assembly and of association, 2016, p. 15; US DOL, 2011, pp. 22-23, 27).

One of the most important problems facing Korean unions is the hostile environment in which they operate. The Korean criminal act allows for heavy fines for trade unionists who are engaged in activities that "obstruct business", even if these activities are non-violent. This basically limits the collective action of unions (Special Rapporteur on the rights to freedom of peaceful assembly and of association, 2016, p. 15; US DOL, 2011, pp. 10-11).
In fact, it is up to the authorities to affirm a strike's legality. This has created significant scope for the authorities to silence opposition. For example, a strike of the Korean Railway Workers not only resulted in the arrest of union members and leaders and the dismissal of workers, but also in lawsuits against the union and some of its officers by KORAIL, demanding about 8 million euro (DAG-EU, 2014; Special Rapporteur on the rights to freedom of peaceful assembly and of association, 2016, p. 15). To quote the UN special rapporteur:

industrial action, particularly strike action, by its nature is designed to interrupt the normal operations of a business or employer in order to press for certain interests; they are inherently disruptive. Strikes should thus be adopted with a great deal of circumspection, but that does not mean they can be arbitrarily suppressed. Criminal and civil liability for loss of revenue or other damages arising from work stoppage negates the very core of the right to strike. (Special Rapporteur on the rights to freedom of peaceful assembly and of association, 2016, p. 15)

\section{How to Understand the Lack of Impact?}

The above leads to the conclusion that the FTAs have not made a difference in the area of enabling rights. ${ }^{17}$ While the FTAs provide output, meaning that they include provisions that reaffirm regulation, and create an institutional infrastructure, this has not let to any impacts in Korea, compared to the pre-FTA situation, with the exception of the creation of institutions and, as Engen (2017, p. 52) argues, more disclosure of violations as a result of the EU DAG's activities. This may increase the empowerment of civil society. However, a causal ultimate impact could not be established.

This failure of the labour provisions in the FTAs to improve enabling rights in Korea could be understood as the result of both endogenous and exogenous factors, the first being those provided by the agreement provisions themselves, the latter being those which are part of the environment in which the agreements were executed.

\subsection{Endogenous Factors}

The total of commitments and procedures that can be derived from the FTAs with Korea are extensive, but underused or simply ineffective. While complaints procedures are included in the US-Korea and Canada-Korea FTAs, Korea has not yet received any complaints (International Cooperation Division, Ministry of Employment

\footnotetext{
15 Migrant workers in general face discrimination and abuse. Even though the Korean government has undertaken some steps to improve their situation, this is not considered to be enough (Committee on the Application of Standards, 2013, p. 38, individual cases).

${ }^{16}$ This change, however, is not seen as an impact of the EU FTA (Soyeon Jeong, Korean labour law attorney, email correspondence, May 26, 2017) even though in 2013 the EU DAG demanded attention for this issue (Engen, 2017, p. 51). An interesting line of research would be to look into if and how the judicial system has responded to the agreements (see for example the article Riethof, 2017, in this issue).

17 Also the other contribution in this thematic issue on the impact of FTAs, the article by Orbie, van den Putte and Martens (2017) on the EU FTA with Peru, shows a lack of positive effects.
} 
and Labor, Government of Korea, personal communication, February 10, 2017; Trade Policy and Negotiations Branch, Foreign Affairs, Trade and Development Canada, Government of Canada, personal communication, April 28, 2017; US DOL, 2017b). Such complaints could make a difference in terms of putting violations on the political map (see Oehri, 2017; Van Roozendaal, 2015), even though they might not actually change the situation. Additionally, the fact that under the same two FTAs obligations with respect to labour can only be violated when they affect trade and investment is also a strong limitation to the application of sanctions, as many of the problems discussed do not necessarily involve sectors which are trade-related. And even if the application were wider, one should keep in mind that sanctions, or the threat of sanctions, do not necessarily lead to (big) improvements (Giumelli \& Van Roozendaal, 2016, p. 19; Greenhill et al., 2009, p. 681; Hafner-Burton, 2005, p. 614).

While an official submissions process is not part of any of the other FTAs, this does not mean that civil society organisations do not undertake any activities. For example, the European DAG (which also includes European employers' representatives) did submit a letter of complaint to the European Commission in January 2014. This letter urged the Commission to invoke consultations with Korea regarding the implementation of the ratified Conventions, and of the ratification of some of the core Conventions and their subsequent implementation, stating that it was "deeply troubled by the Government's blatant disregard for international labour standards in practice" (DAG-EU, 2014). The EU does address labour issues in the Committee on Trade and Sustainable Development (CTSD) (see for example CTSD, 2015), but apparently without much success when it comes to enabling rights. In April 2017, the European Parliament requested that the Commission "take up formal consultations with the Government of Korea...and, if such consultations should fail, call on the panel or experts...to take action and to continue dialogue with regard to the failure of the Korean Government to comply with some of its commitments, and in particular to make continued and sustained efforts...towards ensuring the ratification by Korea of the fundamental ILO Conventions which this country has not ratified yet" (European Parliament [EP], 2017, p. 6).

Only the EU-Korea, New Zealand-Korea and USKorea FTAs allow for the involvement of civil society in terms of monitoring the FTAs. ${ }^{18}$ Such an option does not necessarily lead to success, as van den Putte (2015) shows in a comparison of the strength of the US-Korea and the EU-Korea FTAs in terms of civil society involvement. In the case of the US FTA with Korea, the problem is that the US' national mechanism has to deal with many FTAs' labour provisions while many of the members lack both interest and expertise in South Korea. Van den Putte also considers the US' international mechanism for public involvement to be weak and shows that the situation is only slightly better for the EU-Korea FTA. Similar ineffectiveness is confirmed by a 2016 study commissioned by the Korean branch of the Friedrich Ebert Stiftung (FES) which concludes that "Chapter 13 Trade and Sustainable Development of the Korea-EU FTA failed to be a means of pressure for the South Korean government to bring about substantial changes in the country's labour practices, but only worked to call attention to the matter" (FES, 2016, p. 3). Campling, Harrison, Richardson and Smith (2016) also suggest that the effectiveness in the labour area of the EU-Korea FTA suffers from "the combination of weak domestic advisory groups, a "trade and sustainable development" chapter that lacks any mechanism to arbitrate disputes or impose penalties, and the absence of political will on the part of the EU" (Campling et al., 2016, p. 370). In sum, there is little impact of the FTAs' provisions and procedures on the enabling rights' practices as some, such as sanctions, have not been used whereas other mechanisms have, such as the involvement of civil society, although this has not yet led to concrete effects regarding enabling rights.

\subsection{Exogenous Factor}

The above observation made by Campling et al. (2016), brings us to the main exogenous factor of importance in explaining the ineffectiveness of the FTAs; the lack of political interest, despite the fact that the EU and US, being particularly important export destinations for Korea could have some leverage. ${ }^{19}$ The weak provisions in the labour chapters illustrate, not surprisingly, that the economic goals of FTAs trump normative ones (see for example on the EU-Korea FTA, Frankowski, 2015, p. 14; Gruni, 2017, p. 115).

On the Korean side, the political will to improve labour standards is also lacking, and trade unions operate in an adverse political climate, despite the fact that Korea is a democracy and a developed country. The willingness of the subsequent Korean governments (and especially the conservative ones) to initiate changes to the domestic laws in order to ratify the last four Conventions is lacking (FES, 2016, p. 3; Gruni, 2017, pp. 114-115).

\section{Conclusion}

Korea has signed multiple FTAs, which include labour provisions, even relatively strong ones. The empirical evi-

\footnotetext{
18 While the New Zealand Labour Committee has met at the end of 2016, the records of this meeting are not made public (FTA Implementation Unit, Trade Negotiations Division, New Zealand Ministry of Foreign Affairs \& Trade, email correspondence, February 15, 2017). The records of the two US NAC meetings show that the issues of the obstruction of business code, migrant workers and non-regular workers were only touched upon superficially (NAC, 2013, 2014). The involvement of civil society with respect to the EU-Korea FTA is more comprehensive. Until this date, the EU-DAG has had 13 meetings and the civil society forum five.

19 For Australia, it might even work the other way around, as Korea is its third most important export destination (WTO, 2017b), which might make Australia cautious about making improvement of CLS in Korea to trade an important subject for dialogue.
} 
dence in this research suggests that while there has been an intermediate impact in terms of institution building and the increased international attention for violations, this had no impact on practices in Korea itself. In other words, no relative improvement has taken place, leading to a situation in which the labour provisions serve, from the point of view of stimulating improvements, only a symbolic purpose.

The absence of an ultimate impact can best be explained by the lack of political will on the Korean side (as for example illustrated by the Korean government's references to the incompatibility of some of the ILO Conventions with national law) on the one hand, and an equal lack of readiness on the trade partners' sides to either include strong wording and a strong instrument to back up any commitment, or to actually use the available instruments in a way which would lead to improvement. This comes as no surprise, as the FTAs are first and foremost instruments designed to facilitate trade and investment.

This raises the serious question of whether the inclusion of labour provisions is helpful in improving labour rights when they are not backed up by political will. If one looks at them favourably, the contacts such agreements facilitate between governmental and non-governmental actors may help to increase the willingness and ability to act, even in areas that have no link with trade and investment. However, the current lack of effectiveness of labour provisions in FTAs shows that they should not be seen as a substitute for the other initiatives outlined in this thematic issue.

\section{Acknowledgments}

The author wants to express her gratitude to Paula Köhler for her invaluable research assistance, to members of the trade union, NGO and research community in Korea who provided background information and guidance, to the anonymous reviewers for their comments, to Justine Jones for her language suggestions, and to Jan Orbie for his comments and suggestions on an earlier draft. This article is based on the unpublished paper "Labour Standards as an 'Afterthought' in Trade Agreements: The South Korea Case" that I presented at the 2016 EUIA Conference in Brussels, May 2016.

\section{Conflict of Interests}

The author declares no conflict of interests.

\section{References}

Asia Regional Integration Center. (n.d.). Free trade agreements. Website Asian Regional Integration Center. Retrieved from https://aric.adb.org/fta

Campling, L., Harrison, J., Richardson, B., \& Smith, A. (2016). Can labour provisions work beyond the border? Evaluating the effects of EU free trade agreements. International Labour Review, 155(3), 357-381.
Committee on the Application of Standards. (2013). Extracts from the record of proceedings. Geneva: International Labour Organization.

Committee on the Freedom of Association. (2010). 358 th report of the committee on freedom of association. Case no.2620. Geneva: International Labour Organization.

Committee on the Freedom of Association. (2011). $362^{\text {nd }}$ report of the committee on freedom of association. Case no. 2620. Geneva: International Labour Organization.

Committee on the Freedom of Association. (2013). 367 report of the committee on freedom of association. Case no. 2620. Geneva: International Labour Organization.

Committee on Trade and Sustainable Development. (2015). Joint statement of the $4^{\text {th }}$ meeting of the Committee on Trade and Sustainable Development under the Korea-EU Free Trade Agreement (FTA) in Seoul on 9 September 2015. Brussels: European Commission.

Davies, R., \& Vadlamannati, K. (2013). A race to the bottom in labor standards? An empirical investigation. Journal of Development Economics, 103, 1-14.

Domestic Advisory Group-EU. (2014). Serious violations of Chapter 13 of the EU-Korea FTA. Letter to Karel de Gucht. January 13. Domestic Advisory Group under the EU-Korea FTA. Retrieved from http://www. finunions.org/files/225/Letter_to_Mr_Karel_De_Gu cht_Art_13-_Korea_-FTA.pdf

Durán, G. (2013). Innovations and implications of the trade and sustainable development chapter in the EU-Korea Free Trade Agreement. In J. Harrison (Ed.), The European Union and South Korea: The legal framework for strengthening trade, economic and political relations (pp. 124-146). Edinburgh: Edinburgh University Press.

Engen, L. (2017). Labour provisions in Asia-Pacific Free Trade Agreements (Background paper no.1, Ninth Tranche of the Development Account Project). Bangkok: Economic and Social Commission for Asia and the Pacific.

European Parliament. (2017). Report on the implementation of the Free Trade Agreement between the European Union and the Republic of Korea (Report no. 2015/2059(INI)). Brussels: Committee on International Trade.

Frankowski, P. (2015, June 30-July 1). Labor standards and external promotion of European norms. Paper presented at the Governance and Economic Integration through Free Trade Agreements workshop, Keele, UK. Retrieved from http://giftaproject.org/wpcontent/uploads/2015/07/Frankowski-2015Paper.pdf

Freedom House. (2017). Freedom in the world. Populists and autocrats: The dual threat to global democracy. Freedom House. Retrieved from https:// freedomhouse.org/report/freedom-world/freedomworld-2017

Friedrich Ebert Stiftung. (2016). Evaluation of the Korea- 
EU FTA's labour standards provisions and their implementation status. South Korea: Friedrich Ebert Stiftung.

Giumelli, F., \& Van Roozendaal, G. (2016). Trade agreements and labour standards clauses: Explaining labour standards developments through a qualitative comparative analysis of US free trade agreements. Global Social Policy, 17(1), 38-61.

Greenhill, B., Mosley, L., \& Prakash, A. (2009). Tradebased diffusion of labor rights: A panel study, '19862002'. American Political Science Review, 103(4), 669-690.

Grimmett, J. (2012). Disputes settlement in the U.S.South Korea Free Trade Agreement (KORUS FTA). Washington DC: Congressional Research Service. Retrieved from https://fas.org/sgp/crs/row/ R41779.pdf

Gruni, G. (2017). Labour standards in the EU-Korea Free Trade Agreement. Pushing labour standards into global trade law? Korean Journal of International and Comparative Law, 1(5), 100-121.

Hafner-Burton, E. (2005). Trading human rights: How preferential trade agreements influence government repression. International Organization, 59(3), 593-629.

International Labour Organization. (2012). Fundamental principles and rights at work: From commitment to action. Recurrent discussion under the ILO declaration on social justice for a fair globalization and the follow-up to the ILO declaration on fundamental principles and rights at work (Report VI. Sixth item on the agenda). Retrieved from http://www.ilo.org/ wcmsp5/groups/public/---ed_norm/---relconf/docu ments/meetingdocument/wcms_176149.pdf

International Labour Organization. (2015). Social dimensions of Free Trade Agreements: Revised edition. Retrieved from http://www.ilo.org/wcmsp5/groups/ public/---dgreports/---inst/documents/publication/ wcms_228965.pdf

International Labour Organization. (2017a). Freedom of association and the effective recognition of the right to collective bargaining. International Labour Organization. Retrieved from http://www.ilo.org/ declaration/principles/freedomofassociation/lang-en/index.htm

International Labour Organization. (2017b). Ratifications for Korea, the Republic of. International Labour Organization. Retrieved from http://www.ilo.org/ dyn/normlex/en/f?p=1000:11200:0::NO:11200:P112 00_COUNTRY_ID:103123

International Labour Organization. (2017c). Review of annual reports under the follow-up to the ILO declaration on fundamental principles and rights at work. International Labour Organization. Retrieved from http://www.ilo.org/wcmsp5/groups/public/--ed_norm/---relconf/documents/meetingdocument/ wcms_545463.pdf

International Trade Union Confederation. (2015). Korea:
Supreme court affirms right to unionise for undocumented migrants. International Trade Union Confederation. Retrieved from https://www.ituc-csi.org/ korea-supreme-court-affirms-right?lang=en

International Trade Union Confederation. (2016a). The 2016 ITUC global rights index. The world's worst countries for workers. International Trade Union Confederation. Retrieved from https://www.ituc-csi.org/ IMG/pdf/ituc-violationmap-2016-en_final.pdf

International Trade Union Confederation. (2016b). Description of ratings. International Trade Union Confederation. Retrieved from http://survey.ituc-csi.org/ IMG/pdf/description_of_ratings.pdf

Korean Ministry of Trade, Industry and Energy. (2016). Korea's FTA network. Korean Ministry of Trade, Industry and Energy. Retrieved from http://english.motie. go.kr/en/if/ftanetwork/ftanetwork.jsp

Labour20. (2017). L20 statement to the G20 labour and employment ministers' meeting. International Trade Union Confederation. Retrieved from https:// www.ituc-csi.org/l20-statement-to-the-g20-labour

Meunier, S., \& Nicolaïdis, K. (2006). The European Union as a conflicted trade power. Journal of European Public Policy, 13(6), 906-925.

National Advisory Committee. (2013, March 19). Minutes of meeting of the National Advisory Committee for Labor Provisions in Free Trade Agreements. Washington, DC: United States Department of Labor.

National Advisory Committee. (2014, February 5). Minutes of meeting of the National Advisory Committee for Labor Provisions in Free Trade Agreements. Washington, DC: United States Department of Labor.

Oehri, M. (2017). Civil society activism under US free trade agreements: The effects of actorness on decent work. Politics and Governance, 5(4), 40-48.

Olney, W. (2013). A race to the bottom? Employment protection and foreign direct investment. Journal of International Economics, 91(2), 191-203.

Orbie, J., van den Putte, L., \& Martens, D. (2017). The impact of labour rights commitments in EU trade agreements: The case of Peru. Politics and Governance, 5(4), 6-18.

Potrafke, N. (2013). Globalization and labor market institutions: International empirical evidence. Journal of Comparative Economics, 41(3), 829-842.

Riethof, M. (2017). The international labour standards debate in the Brazilian labour movement: Engagement with Mercosur and opposition to the Free Trade of the Americas. Politics and Governance, 5(4), 30-39.

Special Rapporteur on the rights to freedom of peaceful assembly and of association. (2016). Report of the special rapporteur on the rights to freedom of peaceful assembly and of association on his mission to the republic of Korea (Report No. A/HRC/32/36/Add.2). Geneva: Office of the High Commissioner of the United Nations for Human Rights. Retrieved from https://view.officeapps.live.com/op/view.aspx?src= 
http:\%2F\%2Fwww.ohchr.org\%2FEN\%2FHRBodies\%2 FHRC\%2FRegularSessions\%2FSession32\%2FDocume nts\%2FA_HRC_32_36_Add.2_en.docx.

Underdal, A. (1992). The concept of regime effectiveness. Cooperation and Conflict, 27(3), 227-240.

United States Department of Labor. (2011). Republic of Korea. Labor rights report. Washington, DC: United States Department of Labor.

United States Department of Labor. (2017a). National Advisory Committee for labor provisions of U.S. free trade agreements. United States Department of Labor. Retrieved from https://www.dol.gov/ilab/ trade/agreements/nac.htm

United States Department of Labor. (2017b). Submissions under the labor provisions of Free Trade Agreements. Website United States Department of Labor. Retrieved from https://www.dol.gov/agencies/ ilab/our-work/trade/fta-submissions

United States Department of State. (2010). 2010 Country reports on human rights practices. Washington, DC: United States Department of State.

United States Department of State. (2017). Republic of Korea 2016 human rights report (Updated version). Washington, DC: United States Department of State.

United States Trade Representative. (2007). Correspondence between US Trade Representative Schwab and
Minister for Trade Hyun Chong Kim, June 30, 2007. Retrieved from https://ustr.gov/sites/default/files/ uploads/agreements/fta/korus/asset_upload_file631 12740.pdf

Van den Putte, L. (2015). Involving public society in social clauses and the decent work agenda. Global Labour Journal, 6(2), 221-235.

Van den Putte, L. (2016). The European Union's trade and labour linkage. Beyond the 'soft' approach? (Doctoral dissertation). Ghent University, Ghent, Belgium.

Van Roozendaal, G. (2015). The diffusion of labour standards: The case of the US and Guatemala. Politics and Governance, 3(2), 18-33.

World Bank. (2017). Countries and economies. World Bank. Retrieved from https://data.worldbank.org/ country

World Trade Organization. (2017a). Regional trade agreements. Retrieved from https://www.wto.org/ english/tratop_e/region_e/region_e.htm

World Trade Organization. (2017b). International trade and market access data. World Trade Organization. Retrieved from https://www.wto.org/english/ res_e/statis_e/statis_bis_e.htm?solution=WTO\&path =/Dashboards/MAPS\&file=Map.wcdf\&bookmarkSta te $=\{\% 22$ impl\%22:\%22client\%22,\%22params\%22:\{\% 22langParam\%22:\%22en\%22\}\}

\section{About the Author}

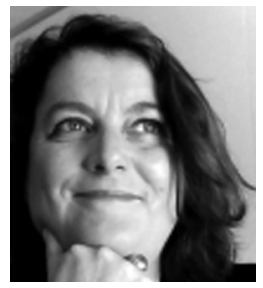

Gerda Van Roozendaal is Associate Professor at the Department of International Relations and International Organization at the University of Groningen. In 2001, she received her PhD from the University of Amsterdam. Van Roozendaal's current research interest is in how (legitimate) institutions develop and in the effectiveness of the linkage between trade agreements and labour standards. 